\title{
Glass fiber post treatment - does it influence resin cement bond strength?
}

\author{
Pinos de fibra de vidro pós tratamento - influencia a resistência de união do \\ cimento resinoso?
}

\begin{abstract}
Marciano de Freitas BORGES ${ }^{a}\left(\mathbb{D}\right.$, Gabriela Simões TEIXEIRA $^{a *}(\mathbb{D}$, Anelise Fernandes MONTAGNER ${ }^{a}\left(\mathbb{D}\right.$, Alexandre Henrique SUSIN ${ }^{a}$
\end{abstract}

aUFSM - Universidade Federal de Santa Maria, Departamento de Odontologia Restauradora, Santa Maria, RS, Brasil

How to cite: Borges MF, Teixeira GS, Montagner AF, Susin AH. Glass fiber post treatment - does it influence resin cement bond strength? Rev Odontol UNESP. 2019;48:e20190032. https://doi.org/10.1590/1807-2577.03219

\begin{abstract}
Resumo
Introdução: Pinos de fibra de vidro são utilizados para melhorar a retenção das restaurações em dentes tratados endodonticamente. Objetivo: Avaliar a resistência de união de pinos de fibra de vidro submetidos a diferentes tratamentos superficiais e cimentados à dentina radicular com cimento resinoso autoadesivo. Material e método: trinta raízes de caninos humanos foram preparadas e divididas de acordo com dois fatores: tratamentos de superfície (silano, peróxido de hidrogênio a 35\% ou bicarbonato de sódio) e o terço radicular (cervical e médio). Os pinos de fibra de vidro foram cimentados com cimento resinoso autoadesivo (RelyX U200) e foram divididos de acordo com duas regiões: cervical e terço médio. Após 24 horas, foram preparados para microtração (formato de ampulheta), padrão de fratura e avaliação micromorfológica por microscopia eletrônica de varredura, para medir a linha de cimento. Resultado: Os dados (MPa e $\mu \mathrm{m}$ ) foram submetidos à ANOVA two-way e teste de Tukey $(\alpha=5 \%)$. Os tratamentos de superfície influenciaram a resistência de união dos pinos. A média da resistência de união (desvio padrão) diferiu de acordo com a região da dentina radicular ( $\mathrm{p}<0,00$ ): a região cervical (Controle: 19,16Mpa (3.71); Silano: 25,65MPa (4.04); Peróxido de hidrogênio: 24,43MPa (3.16); Bicarbonato de sódio: 37,42MPa (8.27)) apresentou valores de resistência a raiz (Controle: 14,66MPa (4.65); Silano: 12,52MPa (5.03); peróxido de hidrogênio: 10,64MPa (3.33); bicarbonato de sódio: 10,87MPa (2.49)). Conclusão: 0 tratamento com agentes químicos e físicos aumentou a resistência de união da interface cimento-pino-dentina no terço cervical e o tratamento com bicarbonato de sódio apresentou melhores resultados na resistência de união.
\end{abstract}

Descritores: Cimento resinoso; pino de fibra; tratamento de superfície; adesão; dentina.

\begin{abstract}
Introduction: Glass-fiber posts are used in order to improve the retention of restorations in endodontically treated teeth. Objective: To evaluate the bond strength of glass-fiber posts submitted to different surface treatments and cemented to the root canal dentin with self-adhesive resin cement. Material and method: Thirty roots of human canines were prepared and divided according to two factors: surface treatments (silane, 35\% hydrogen peroxide, or sodium bicarbonate) and root thirds (cervical and middle thirds). The glass-fiber posts were cemented with self-adhesive resin cement (RelyX U200). After $24 \mathrm{~h}$, the specimens were prepared for microtensile bond strength test (hourglass format), fracture pattern and micromorphological assessment by scanning electronic microscopy, in order to measure the cement line. Result: The data (MPa and $\mu \mathrm{m}$ ) were submitted to two-way ANOVA and Tukey's test ( $\alpha=5 \%$ ). The surface treatments influenced the bond strength of the posts cemented with self-adhesive resin cement $(\mathrm{p}<0.00)$. The mean bond strength (standard deviations) differed according to the region of root dentin $(\mathrm{p}<0.00)$ : the cervical region (Control: 19.16MPa (3.71); Silane: 25.65MPa (4.04); Hydrogen peroxide: 24.43MPa (3.16); Sodium bicarbonate: $37.42 \mathrm{MPa}$ (8.27)) showed higher bond strength values than the middle third of the root (Control: 14.66MPa (4.65); Silane: 12.52MPa (5.03); Hydrogen peroxide: 10.64MPa (3.33); Sodium
\end{abstract}


bicarbonate: $10.87 \mathrm{MPa}(2.49))$. Conclusion: Treatment of the glass-fiber post surface with chemical and physical agents increased the bond strength of the cement-post-dentin interface in the cervical third and the treatment with Sodium bicarbonate showed better results in bond strength.

Descriptors: Resin cement; fiber post; surface treatment; adhesion; dentin.

\section{INTRODUCTION}

A cementing agent is used to retain the intraradicular post in the root canal. Prefabricated glass-fiber posts are widely used to secure restorations of endodontically treated teeth.

Retention of the glass-fiber post inside the root canal depends on how well the cement adheres to the dentin, since most adhesive failures occur at the cement-dentin interface ${ }^{1,2}$, owing to loss of adhesion to the complex root dentin ${ }^{3}$. Moreover, effective adhesion of the cement to the post is also important to ensure the satisfactory distribution of forces induced along the root, thus minimizing the risk of root fracture.

Glass-fiber posts are composed of longitudinal silicon dioxide and alumina fibers surrounded by a Bis-GMA matrix of cycloaliphatic amines, such as epoxy resins, reinforced with inorganic particles. Since the elasticity modulus of the posts is similar to that of dentin ${ }^{4}$, the force applied to the tooth is absorbed, with a consequent reduction in the transmission to the tooth structure, thereby distributing the stresses more evenly along the root, and reducing the risk of root fracture ${ }^{5}$.

It has been reported that the polymeric matrix of the glass-fiber post does not react chemically with the monomers of the resin cement; hence, the surface of the fiber posts is treated to improve its binding to the resin cement ${ }^{3}$. A number of possible post surface treatments have been proposed including: chemical treatments such as silane, acids and peroxides; physical treatments, such as blasting with aluminum oxide and sodium bicarbonate; and a combination of both physical and chemical methods ${ }^{6}$. Chemical treatment is considered the most suitable method, because it is less aggressive, easier to apply and cheaper, in addition to cleaning the post surface, thus improving the interaction between the glass-fiber and the resin cement ${ }^{7}$. Accordingly, since both physical surface and combined treatments are widely available in both the clinical and the laboratory setting, they should not be overlooked.

Mechanically, adhesive circumferential joints containing two or more interfaces represent a monoblock. Thus, the dentin-cement-post combination presents a physical behavior inherent to monoblocks ${ }^{8}$, a condition dependent on the adhesion among the materials involved and the substrate where they are inserted. Therefore, the success of the reconstruction of a fragile dental structure depends on the mechanical behavior of each element involved in the formation of the set.

The aim of this study was to evaluate the effect of fiber post surface treatments on the bond strength of a self-adhesive cement in the cervical and middle region of the root. The null hypothesis tested is that surface treatments of the intraradicular glass-fiber posts should not interfere the bond strength.

\section{MATERIAL AND METHOD}

This was an in vitro study assessing the bond strength of a self-adhesive resin cement to dentin and posts. The study was approved by the Local Ethics Committee (\#684.810).

Thirty human maxillary canine teeth extracted for periodontal reasons were selected, cleaned and stored in $0.05 \%$ chloramine $\mathrm{T}$ solution, in a refrigerator. Teeth with caries, restorations, endodontic treatments, cracks or fractures were excluded. In addition, only teeth with a minimum 
cervical diameter of $6 \mathrm{~mm}$ and a root length from the cement-enamel junction (CEJ) of $15 \mathrm{~mm}$ ( $\pm 1 \mathrm{~mm}$ ) were included.

Six teeth were produced for microscopy assessment. The variables were: glass-fiber post surface treatment (without treatment, with silane, 35\% hydrogen peroxide, or sodium bicarbonate) and the root dentin region (cervical and middle third).

\section{Endodontic Procedures}

The tooth crowns were separated from the roots $2 \mathrm{~mm}$ above the CEJ, using a diamond saw under constant irrigation, in a Labcut 1010 cutting machine (Extec Corp., Enfield, CT, USA). The roots were subjected to endodontic treatment with the ProTaper Universal system (DentsplyMaillefer, Ballaigues, Switzerland), using a hand-held rotary system at low speed (X-smart - Dentsply). The same trained operator prepared all the teeth. The cervical and middle thirds of the roots were initially prepared using the S1, SX and S2instruments. Then, S1, S2, F1, F2, and F3 files were used in this sequence along the working length (WL), until the instrument no longer provided resistance inside the root canal. The root canals were irrigated with $3 \mathrm{ml}$ of $2 \%$ sodium hypochlorite solution before each change of instrument. A type \#30 k-file was inserted in the WL to assure uniformity of the apical diameter after each preparation. The canals were irrigated with $2 \mathrm{ml} 17 \%$ ethylenediaminetetraacetic acid solution (EDTA) for $3 \mathrm{~min}$ and then washed with $2 \mathrm{ml}$ of distilled water.

Following the endodontic procedure, the canal was prepared to approximately $12 \mathrm{~mm}$ $( \pm 1 \mathrm{~mm}$ ) in length using a post \#1 post-standardizing drill bit provided by the manufacturer. The canals were washed with destilled water for 1 minute and dried with diameter \#30 absorbent paper tips (DentsplyMaillefer).

\section{Post Surface Treatment and Cementing}

Twenty-four prepared roots were randomly allocated into 4 groups $(n=6)$, according to the surface treatment to be performed on the glass-fiber post (Table 1). The materials used are described in Table 1, and the treatment protocols are described in Table 2. Once ascertaining adaptation of the posts by juxtaposing inside the canals, the posts underwent surface treatment and were cemented inside the root canals with U200 resin cement (Table 3). The cement was used according to the manufacturer's instructions. It was inserted into the root canal using a Centrix syringe (DFL, Rio de Janeiro, Brazil) with a metal cannula. The root canal was filled until the cement overflowed. The post was then inserted into the root canal and the excess cement was removed with cotton. The post was maintained under finger pressure during chemical polymerization, and then left undisturbed for6 minutes to allow the chemical to curing the cement. Additionally, the resin cement was photo-cured for 60 seconds with a Radii-cal LED photocuring device (SDI, Victoria, Australia), at monitored intensity of $1200 \mathrm{~mW} / \mathrm{cm}^{2}$.

Table 1. Materials used in the surface treatment steps and cementation of the fiber post

\begin{tabular}{cccc}
\hline Materials & Product & Manufacturer & Batch no. \\
\hline Glass-Fiber Post & Exacto \#1 & Angelus, Londrina, PR, Brazil & 38064 \\
Resin Cement & RelyX U200* & 3M ESPE, Germany & 1402400622 \\
35\% Hydrogen Peroxide & Whiteness HP & FGM, Joinville, SC, Brazil & 25814 \\
Silane & Silane & Angelus, Londrina, PR, Brazil & 36339 \\
Sodium Bicarbonate & Sodium Bicarbonate & Polident, Cotia, SP, Brazil & 46482 \\
\hline
\end{tabular}

*Also available as RelyXUnicem 2. 
Table 2. Post surface treatments protocols

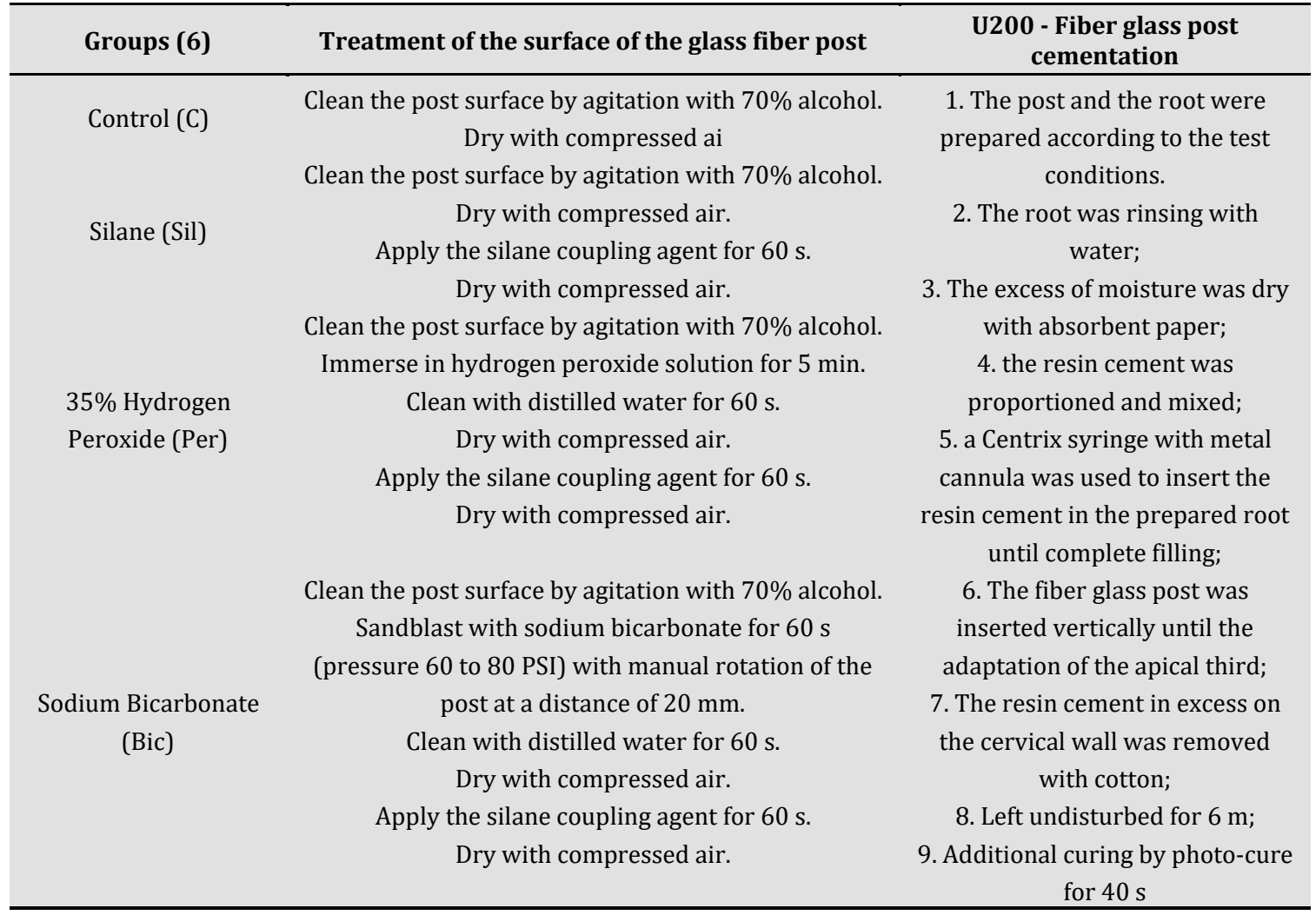

Table 3. Composition of resin cement

\begin{tabular}{c}
\hline Composition \\
\hline Glass powder, surface modified with 2- propenoic acid, 2 methyl-.3- \\
(trimethoxysilyl) propyl, bulk material \\
Substituted dimethacrylate \\
1,12-dodecane dimethycrylate \\
Ed dimethacrylate \\
RelyX U200* $2,4,6(1 \mathrm{~h}, 3 \mathrm{~h}, 5 \mathrm{~h})$-pyrimidinetrione, 5 -phenyl-1- (phenylmethyl)-, calcium salt \\
(2:1) \\
Silane treated silica \\
Sodium p-2-propenoic acid, 2-methyl-, [(3- methoxypropyl)imino]di-2,1- \\
ethanediyl ester toluenesulfinate \\
Calcium hydroxide \\
Methacrylateamine \\
NUC- titanium dioxide
\end{tabular}

*Also available as RelyXUnicem 2.

\section{Microtensile Test}

The samples were stored for 24 hours in distilled water at $37^{\circ} \mathrm{C}$. Cross sections were made in the root using a Labcut 1010 cutting machine fitted with a diamond saw (Extec Corp. Enfield, CT, USA), and 4 slices with a thickness of $1 \mathrm{~mm}$ were obtained from each of the root thirds (cervical and middle thirds).The corresponding slices of the apical third were not included in the study, because of the numerous pretest failures. The slices were prepared for the microtensile test in an hourglass format, as proposed by Goracci et al. ${ }^{9}$ (Figure 1). The area of the cross section was calculated using the formula, according to Mallmann et al. ${ }^{10}: \boldsymbol{A}=\boldsymbol{C P} / \mathbf{2}-\boldsymbol{D B D} \times \boldsymbol{T}$; where: $\boldsymbol{A}=$ Area; $C P=$ Circumference of the post; $D B D=$ Diamond bur diameter; $T=$ Specimen thickness. 


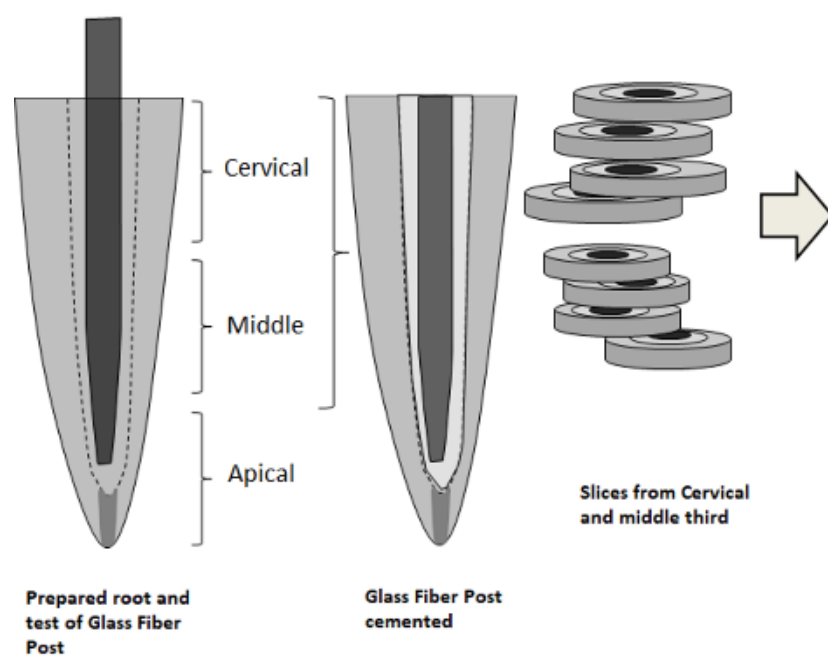

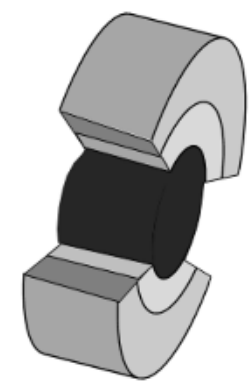

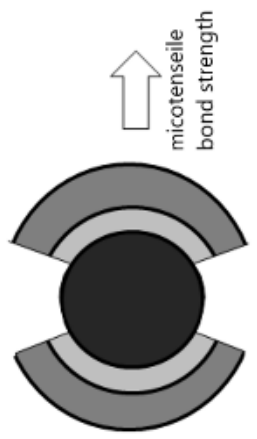

Slices in form of

hourglasses. Ready to

microtensile bond

strength test

Figure 1. Preparation slices. The schematic view shows the sequence of obtaining specimens in form of "hourglasses" to be tested (microtensile bond strength). From the cervical and medium third were obtained slices and then, they were prepared. Root wall and resin cement (dark grey and light grey, respectively) were removed by a diamond bur ( 2135 - KG Sorensen, Barueri, Brazil) until exposing laterally the periphery of the fiber glass post (black) ${ }^{11}$.

The specimens were bonded in the device and tested for $\mu$ TBS in a EMIC DL 1000 testing machine (Instron Instruments Brazil, S.J. dos Pinhais, Brazil) - load cell of $0.5 \mathrm{~N}$ at $0.5 \mathrm{~mm} / \mathrm{s}$ of crosshead speed until disruption.

\section{Fracture Analysis}

After completing the microtensile test, all the samples were analyzed using a stereoscopic (Discovery V20, Carl-Zeiss, LLC, USA) at 30X magnification to analyze the failure mode, which was classified into three types: adhesive failure between cement and dentin, adhesive failure between cement and post, or mixed failure-a combination of the two aforementioned failures. A previously trained and blinded operator carried out the failure mode evaluation.

\section{Scanning Electron Microscope Analyses}

The cement line thickness and the surface of the conditioned posts were analyzed using a scanning electron microscope (SEM). Six teeth were prepared according to the same protocol used for the control group, to measure the thickness of the cement line in the cervical and middle thirds. A longitudinal cut was made in the center of the root in order to dissect the conduit-cement-post assembly longitudinally, and each cross section was divided into three parts according to the root third. The cross sections were polished with 600 and 1000-grit sandpaper for 1 minute by a mechanical rotary polisher, under abundant irrigation. The samples were dried with absorbent paper and fixed chemically by immersion in $2.5 \%$ glutaraldehyde solution buffered with sodium cacodylate $0.1 \mathrm{M}$ for 4 hours. After incubation, the samples were subjected to a chemical drying process in increasing concentrations of ethanol: $25 \%$ for 10 minutes, $50 \%$ for 20 minutes, $75 \%$ for 20 minutes, and absolute alcohol for 5 minutes. The tested specimens were sputter-coated (Denton Vacuum, DESK II, Moorestown, USA) and analyzed under a SEM (JSM-6360, JEOL, Japan) at 120X magnification.

The thickness of the cement line was measured in the cervical and middle third. Three measurements were performed directly by SEM with 180x of magnification on each image at 
predetermined locations of the cement-post interface: in the center of the image, each 100 micrometers to the left (twice), and each 100 micrometers to the right (twice). The average of the five measures on each image was considered as thickness of cement line the specimen.

\section{Statistical Analysis}

Data from the microtensile bond strength $(\mathrm{MPa})$ and measurements of the cement line thickness were subjected to two-way ANOVA at 5\% statistical significance, and Tukey's post-hoc test was used to assess the significant differences among the groups. The tests were conducted using SPSS (Statistical Package for Social Sciences, 20.0).

\section{RESULT}

\section{Microtensile Bond Strength}

The bond strength values of the microtensile test, and the thickness of the cement line for all the groups are shown in Table 4.

Table 4. Mean (SD) bond strength (MPa) and mean thickness of cement line $(\mu \mathrm{m})$ for each experimental group and dentin root region

\begin{tabular}{ccccccc}
\hline & \multicolumn{5}{c}{ Group } \\
\cline { 2 - 6 } Root Region & Control (C) & Silane (Sil) & $\begin{array}{c}\text { 35\% } \\
\text { Hydrogen } \\
\text { Peroxide (Per) }\end{array}$ & $\begin{array}{c}\text { Sodium } \\
\text { Bicarbonate (Bic) }\end{array}$ & $\begin{array}{c}\text { Thickness of } \\
\text { cement line }\end{array}$ \\
\hline Cervical & $19.16(3.71) \mathrm{Ba}$ & $25.65(4.04) \mathrm{Ba}$ & $24.43(3.16) \mathrm{Ba}$ & $37.42(8.27) \mathrm{Aa}$ & $762^{*}$ \\
Middle & $14.66(4.65) \mathrm{Aa}$ & $12.52(5.03) \mathrm{Ab}$ & $10.64(3.33) \mathrm{Ab}$ & $10.87(2.49) \mathrm{Ab}$ & 414 \\
\hline
\end{tabular}

Different uppercase letters indicate statistical significance in lines. Different lowercase letters and “*” indicate statistical significance in columns. $(\mathrm{p}<0.05)$.

Considering the root regions, that of the root dentin affected the bond strength values and led to statistically significant differences between the areas studied $(p<0.00)$, in that the cervical third (overall mean 26.6 MPa) showed higher bond strength values than the middle third (overall mean $12.2 \mathrm{MPa}$ ).It was observed that the different surface treatments influenced the bond strength of the glass-fiber post cemented with self-adhesive resin cement and the root region, as well as the interaction between the post surface treatment and the root region, all presenting $\mathrm{p}<0.00$.

\section{Failure Patterns}

The data on the failure standards was analyzed descriptively. Adhesive failures between the cement and the dentin in the middle third of the root were the most common failure mode for all the post surface treatments tested. However, the prevalent distribution for cement-post or cement-dentin adhesive failures or mixed failures varied in the cervical third according to the post surface treatment used (Table 5). 
Table 5. Percentage of failures (root thirds)

\begin{tabular}{ccc}
\hline Group & Cervical & Middle \\
\hline \multirow{3}{*}{ Control (C) } & Cement-dentin 25\% & Cement-dentin 77\% \\
& Cement-post 50\% & Cement-post 33\% \\
& Mixed 25\% & Mixed 0 \\
Silane (Sil) & Cement-dentin 25\% & Cement-dentin 70\% \\
& Cement-post 40\% & Cement-post 12\% \\
& Mixed 35\% & Mixed 18\% \\
Hydrogen Peroxide (Per) & Cement-dentin 43\% & Cement-dentin 88\% \\
& Cement-post 24\% & Cement-post 6\% \\
& Mixed 33\% & Mixed 6\% \\
Bicarbonate (Bic) & Cement-dentin 27\% & Cement-dentin 87\% \\
& Cement-post 27\% & Cement-post 13\% \\
\end{tabular}

\section{SEM Analyses}

\section{Thickness of the Cement Line}

There was a statistically significant difference among the cement line thicknesses in the different regions $(\mathrm{p}=0.01)$. The mean thickness of the cement line was $762 \mu \mathrm{m}$ in the cervical third and $414 \mu \mathrm{m}$ in the middle third (Figure 2).

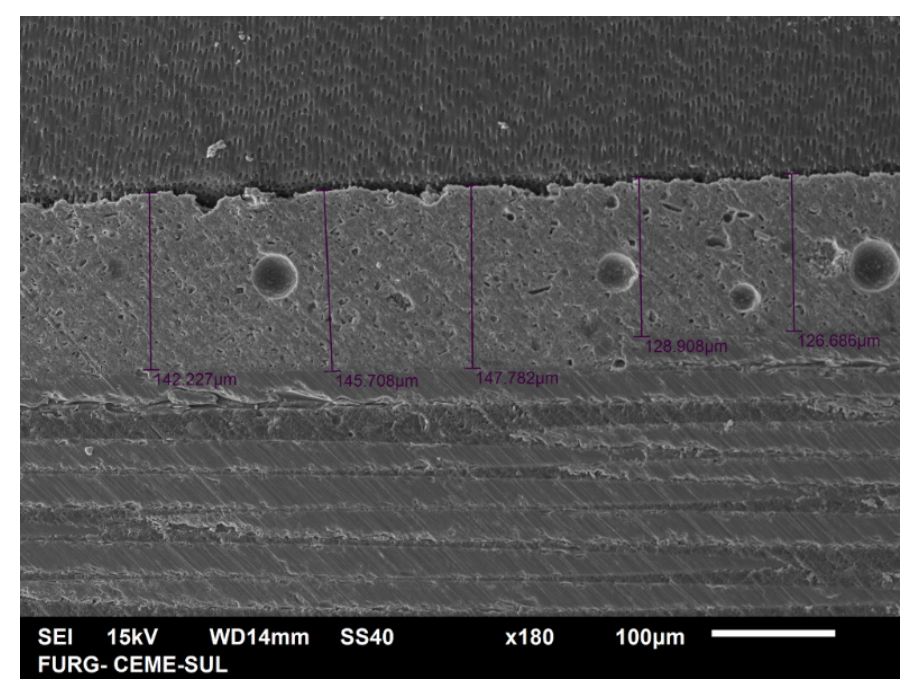

Figure 2. SEM - Cement line thickness. The five measures of cement line (vertical lines).

\section{Effect of Surface Treatment on Posts}

Figure 3 shows the surfaces of glass-fiber post that did not undergo surface treatment (Figure 3 "A"), those that that were treated with the coupling agent (silane - Sil) (Figure 3 "B"), and those that underwent surface treatment with $35 \%$ hydrogen peroxide (Per) (Figure 3 " $\mathrm{C}$ ") or sodium bicarbonate (Bic) (Figure 3 "D"). The posts treated with Per and Bic showed a clean surface and removal of part of the resin matrix, exposing the glass-fiber of the post. Figure 4 shows cement-resin tags in the cement-dentin interface. 

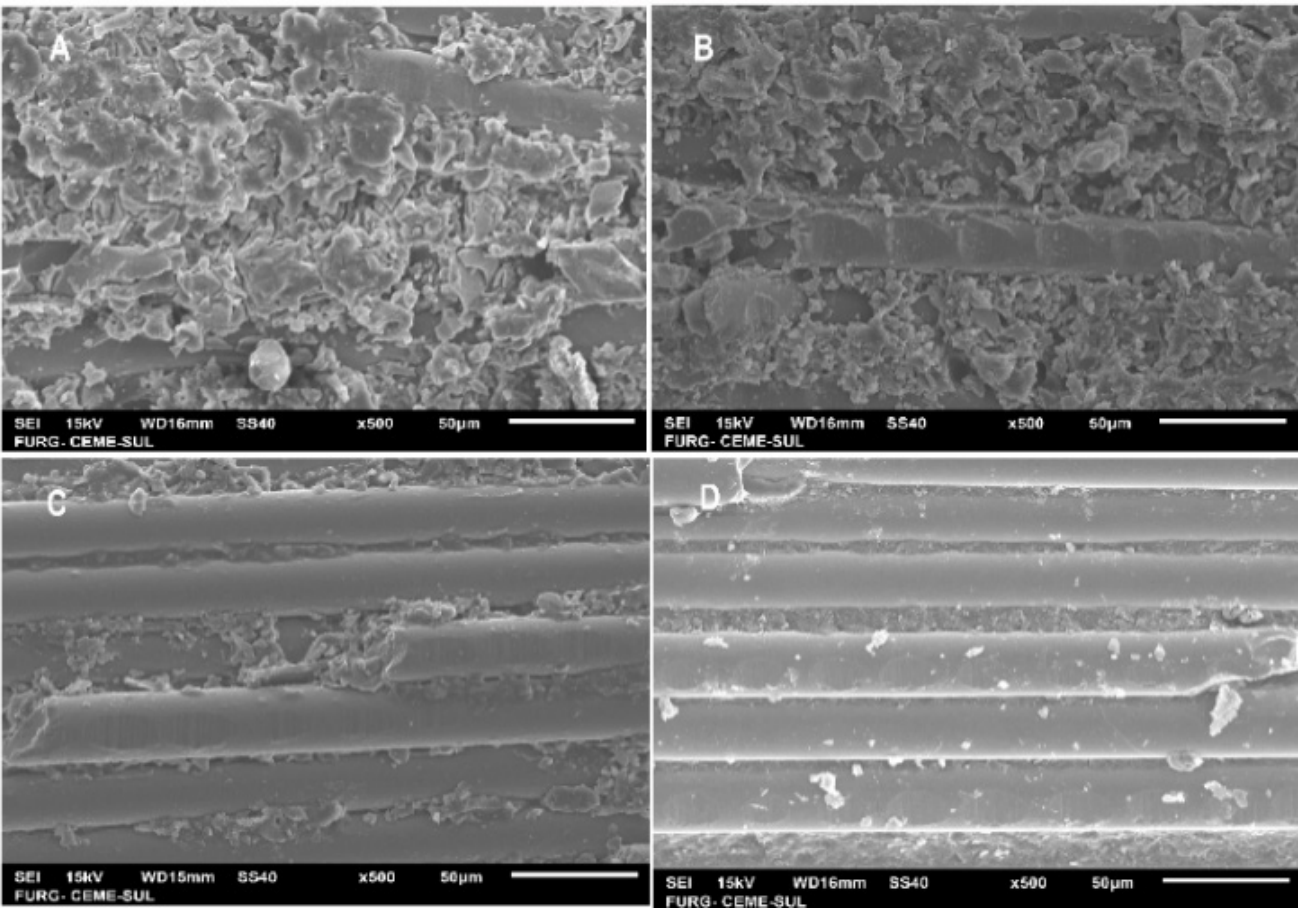

Figure 3. SEM (500X) Surface of fiberglass: $A=$ Control; $B=$ Silane; $C=35 \%$ Hydrogen Peroxide and $\mathrm{D}=$ Sodium Bicarbonate. The fiber glasses, longitudinally of the post, are superficially exposed.

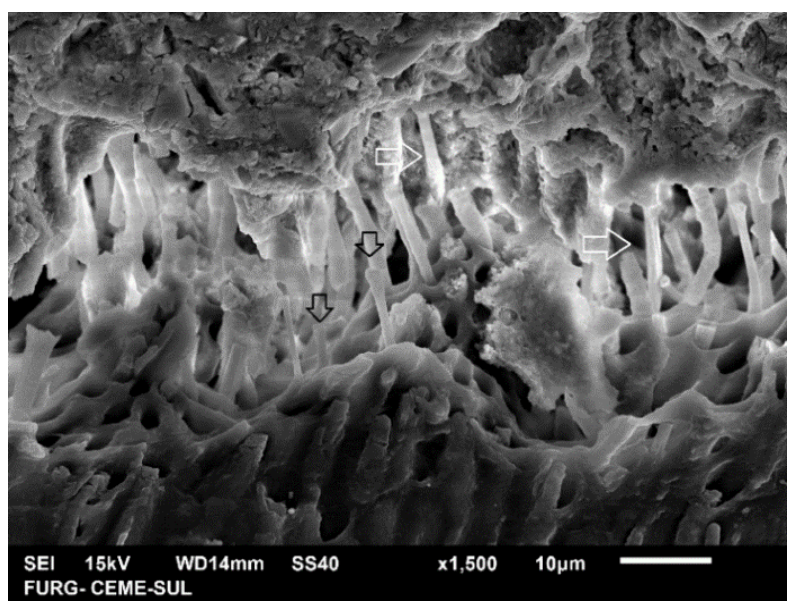

Figure 4. SEM (1500X) Resin Cement - Dentin interface gap. Cement-resin tags emerging from resin cement to dentin tubules. (white arrows). Cement-resin tags fractured are shown (black arrows). The resin cement shrinkages or the technical preparation to microscopy (acid rinsing to remove smear layer formed by 1200 -grit silicon carbide paper or drying process) promoted this effect.

\section{DISCUSSION}

Several studies have evaluated the effect of dentin surface treatment on bond strength after cementation of intraradicular post, as the presence of smear layer and debris along the prepared root canal walls can also affect dentin adhesion ${ }^{12}$. Irrigating solution, such as EDTA 17\%, used in this study before the cementation of the post, has its use consolidated in the literature, because it removes smear layer, but does not totally demineralize dentin, allowing the interaction of dentin inorganic substances with resin cement ${ }^{13}$, because the chemical characteristics of cement also influence the bond strength, the presence of the smear layer can be overcome by the possible 
chemical bond between dentin and the cement itself, which, in the case of U200 cement, is ensured by presence of trimellitic 4-methacry-loxythyl acidic monomers and phosphoric acid ether ${ }^{14}$.

The surface treatment made with sodium bicarbonate on the post surfaces improved the bond strength in the cervical region groups, compared with the other treatments. Comparing the results for the cervical versus middle regions, we found no differences except for the control groups, whereas the Sil, Per and Bic treated groups had higher bond strength results in the cervical third. Therefore, we partially reject the first hypothesis, and reject the second one.

The conditioning agents and techniques used in this study can be easily used in a clinical setting, since they are materials available in clinical practice, and the techniques are both simple to perform and require no special or expensive equipment. The agents used also have a surface cleaning effect (Figure 3) and may change the surface energy, depending on the type of conditioner employed ${ }^{15}$. Furthermore, some acid conditioners may also expose the fibers in the posts, due to dilution of their resin phase, leading to improved interaction with the bonding agent $^{7}$. This effect can readily be seen in the results obtained for the Per (Figure 3C) and Bic (Figure 3D) groups.

It has been reported that the treatment of posts with hydrogen peroxide and mechanical blasting with aluminum oxide yield higher bond strength. This is because the treatment promotes the formation of irregularities (micro-retentions) in the post. Furthermore, it has been found that blasting of the post with aluminum oxide followed by the application of $35 \%$ hydrogen peroxide results in improved surface cleaning, leading to increased bond strength ${ }^{16}$.

In the present study, the enamel was blasted with sodium bicarbonate to remove bacterial plaque and extrinsic stains ${ }^{17}$.The blasting was also used to provide a mechanical surface treatment of the glass-fiber post, thus creating irregularities on the glass-fiber post surface following removal of the resin matrix (Figure 3D), and promoting cleaning, thereby enhancing the bond strength.

It was found that the application of silane enhanced the bond strength in all the experimental groups, compared with the control group. Silane is a bifunctional agent that promotes chemical interactions between organic and inorganic compounds. Thus, the organic matrix of the resin cement and the silica present in the glass-fiber of the posts are chemically linked, and provide better wetting capacity of the surface by the cementing agent ${ }^{14}$. According to Nishiyama et $a^{2}{ }^{2}$, the properties of an interface in which one of the components is silanized are influenced by the quantity of the agent adsorbed, and by the chemical affinity of the components of the assembly. The presence of methacrylate acid monomers in the resin cement formula promotes surface conditioning of the post, and triggers a chemical interaction between the resin cement and the glass fiber ${ }^{18}$. The findings of this study can be explained through the hybridization mechanism for self-adhesive cement described above. Similar results have been presented by Machado et al. ${ }^{19}$.

Leme et al. ${ }^{20}$ recommended the use of silane as an agent for enhancing adhesion. They used glassfiber posts cemented with a self-adhesive resin cement (RelyXUnicem) containing phosphate methacrylate acid monomers, similar to the cement used in this study. However, studies by Machado et al. ${ }^{19}$ showed that merely applying silane or hydrogen peroxide did not increase post retention, as shown in comparisons with the control group. Therefore, these authors recommend combining post surface treatments with silane to reinforce the post-dentin bond. Note that combining different techniques may result in a longer clinical application time, due to a greater number of steps involved prior to the cementation of the post. Therefore, combined treatment protocols were not examined in this study, inasmuch as our main purpose was to verify the effect of the treatments individually, so that each effect could be assessed separately.

The present study showed a difference among the bond strength values in different root regions. Comparing all the treatments tested, the results for the cervical third were better than those for the middle third. This difference may be attributed to several factors, such as the morphological differences between the crown and root dentinal substrates. The dentin located in 
the cervical third maintains many micromorphological characteristics of the dentin located in the dental crown, like amplitude and number of dentinal tubules, as well as mineral and organic composition, thus making it more suitable to conduct adhesive procedures. The number of dentinal tubules in the dental crown is different from that of the cervical third, and the number decreases in the cervico-apical direction, influencing the adhesive strength, which gradually decreases as the distance from the cervical region increases ${ }^{20}$.

Another aspects related to the cavity configuration factor (C-Factor), whose significant influence on the adhesive bond was demonstrated by the decrease in bond strength values between the cervical and middle thirds. Our data is consistent with a prior study by Perdigão et al. ${ }^{21}$.These studies showed that the C-factor is associated with lower adhesive strength at the lower root thirds, which is explained by the larger circumferential area, and consequent greater volume of resin cement in the cervical third. No significant influence was found for the post and cavity wall acting as a confinement factor, since there is greater space in the root region, thus allowing for relaxation of the stresses induced during polymerization contraction. These results are consistent with those of our study; the cement line thickness results were significantly greater in the cervical third (Figure 2), coinciding with the higher bond strength results in this region 22 .

The bond may be enhanced due to chemical interactions between components of the cement and post with the substances used for surface treatment. Although the $\mathrm{pH}$ of self-adhesive cement is initially acidic, the conditioning provided by this cement differs from that provided by phosphoric acid ${ }^{23}$.

Although the most suitable test to evaluate the bond strength between intraradicular posts and the root dentin has been reported as the push-out test ${ }^{9}$, the microtensile test was used in this study to provide a more ad hoc evaluation of the adhesive interface in the different root regions. According to Goracci et al. ${ }^{9}$, this type of mechanical test can measure the bond strength between minimal surfaces and evaluate the local variations in the tooth substrate. It is also suitable for obtaining multiple samples from a single tooth. Preparation of the specimens in the form of an hourglass, as performed in this study, can lead to a high number of pretest failures and limit the number of samples used. This type of preparation can create additional stress in the sample and influence early losses, according to Armstrong et al. ${ }^{24}$. However, it is important to highlight that the highest number of failures invariably occurs in the apical third, which was not the object of this study. Moreover, the data obtained in this study proved to be reliable, and the number of pretest failures was negligible.

Adhesion of the glass-fiber post to the root dentin may also be affected by the difficulty in controlling the intraradicular moisture, because it is difficult to view the canal along its entire length. As a consequence, there can be deficiencies in the conduit drying stage ${ }^{1,22}$.

Regarding the failures presented in this study, the fact that all were adhesive and predominantly in the cement-dentin interface confirms the suitability of the method proposed, this is corroborated by the previous studies ${ }^{21}$. The hourglass shape as sample geometry allowed the stresses to be irregularly distributed to the region studied and data obtained on the interface should be influenced by standard deviation values, however all groups suffered with that influence. According to Goracci et $\mathrm{al}^{25}$, high standard deviation values may also be associated with the constant handling of the sample, such as the lateral wear required for its preparation. Henceforth, this bias should be controlled in the other in vitro studies.

\section{CONCLUSION}

Within the limitations of the present experiment, it can be concluded that the treatment of the glass-fiber post surface with the chemical and physical agents increased the bond strength in the cervical third of the root, and the treatment with Bic promoted better results than the others. 


\section{REFERENCES}

1. Van Meerbeek B, De Munck J, Yoshida Y, Inoue S, Vargas M, Vijay P, et al. Buonocore memorial lecture. Adhesion to enamel and dentin: current status and future challenges. Oper Dent. 2003 MayJun;28(3):215-35. PMid:12760693.

2. Nishiyama N, Komatsu K, Fukai K, Nemoto K, Kumagai M. Influence of adsorption characteristics of silane on the hydrolytic stability of silane at the silica-matrix interface. Composites. 1995 Apr;26(4):309-13. http://dx.doi.org/10.1016/0010-4361(95)93674-9.

3. Menezes MS, Faria-e-Silva AL, Silva FP, Reis GR, Soares CJ, Stape TH, et al. Etching a fiber post surface with high-concentration bleaching agents. Oper Dent. 2014 Jan-Feb;39(1):e16-21. http://dx.doi.org/10.2341/12-270-L. PMid:23848068.

4. Coelho CS, Biffi JC, Silva GR, Abrahão A, Campos RE, Soares CJ. Finite element analysis of weakened roots restored with composite resin and posts. Dent Mater J. 2009 Nov;28(6):671-8. http://dx.doi.org/10.4012/dmj.28.671. PMid:20019417.

5. Drummond JL. In vitro evaluation of endodontic posts. Am J Dent. 2000 May;13(Spec No):5B-8B. PMid:11763868.

6. Valandro LF, Yoshiga S, Melo RM, Galhano GA, Mallmann A, Marinho CP, et al. Microtensile bond strength between a quartz fiber post and a resin cement: effect of post surface conditioning. J Adhes Dent. 2006 Apr;8(2):105-11. PMid:16708722.

7. Gonçalves AP, Ogliari AO, Jardim PS, Moraes RR. Chemical cleaning agents and bonding to glass-fiber posts. Braz Oral Res. 2013 Jan-Fev;27(1):70-2. http://dx.doi.org/10.1590/S180683242013000100012 . PMid:23306628.

8. Tay FR, Pashley DH. Monoblocks in root canals: a hypothetical or a tangible goal. J Endod. 2007 Apr;33(4):391-8. http://dx.doi.org/10.1016/j.joen.2006.10.009. PMid:17368325.

9. Goracci C, Grandini S, Bossù M, Bertelli E, Ferrari M. Laboratory assessment of the retentive potential of adhesive posts: a review. J Dent. 2007 Nov;35(11):827-35. http://dx.doi.org/10.1016/j.jdent.2007.07.009. PMid:17766026.

10. Mallmann A, Jacques LB, Valandro LF, Mathias P, Muench A. Microtensile bond strength of light- and self-cured adhesive systems to intraradicular dentin using a translucent fiber post. Oper Dent. 2005 Jul-Aug;30(4):500-6. PMid:16130871.

11. Mallmann A, Jacques LB, Valandro LF, Muench A. Microtensile bond strength of photoactivated and autopolymerized adhesive systems to root dentin using translucent and opaque fiber-reinforced composite posts. J Prosthet Dent. 2007 Mar;97(3):165-72. http://dx.doi.org/10.1016/j.prosdent.2007.01.008. PMid:17394915.

12. Oliveira LV, Maia TS, Zancopé K, Menezes MS, Soares CJ, Moura CCG. Can intra-radicular cleaning protocols increase the retention of fiberglass posts? A systematic review. Braz Oral Res. 2018 Mar;32(0):e16. http://dx.doi.org/10.1590/1807-3107bor-2018.vol32.0016. PMid:29561949.

13. Moura AS, Pereira RD, Rached FJ, Crozeta BM, Mazzi-Chaves JF, Souza-Flamini LE, et al. Influence of root dentin treatment on the push-out bond strength of fibre-reinforced posts. Braz Oral Res. 2017 Apr;31(0):e29. http://dx.doi.org/10.1590/1807-3107bor-2017.vol31.0029. PMid:28403332.

14. Simões TC, Luque-Martinez Í, Moraes RR, Sá A, Loguercio AD, Moura SK. Longevity of bonding of selfadhesive resin cement to dentin. Oper Dent. 2016 May-Jun;41(3):e64-72. http://dx.doi.org/10.2341/14-266-LR. PMid:26918926.

15. Goracci C, Raffaelli O, Monticelli F, Balleri B, Bertelli E, Ferrari M. The adhesion between prefabricated FRC posts and composite resin cores: microtensile bond strength with and without post-silanization. Dent Mater. 2005 May;21(5):437-44. http://dx.doi.org/10.1016/j.dental.2004.07.012. PMid:15826700. 
16. Liu C, Liu H, Qian YT, Zhu S, Zhao SQ. The influence of four dual-cure resin cements and surface treatment selection to bond strength of fiber post. Int J Oral Sci. 2014 Mar;6(1):56-60. http://dx.doi.org/10.1038/ijos.2013.83. PMid:24177170.

17. Bühler J, Schmidli F, Weiger R, Walter C. Analysis of the effects of air polishing powders containing sodium bicarbonate and glycine on human teeth. Clin Oral Investig. 2015 May;19(4):877-85. http://dx.doi.org/10.1007/s00784-014-1317-z. PMid:25240922.

18. Pereira RD, Valdívia AD, Bicalho AA, Franco SD, Tantbirojn D, Versluis A, et al. Effect of photoactivation timing on the mechanical properties of resin cements and bond strength of fiberglass post to root dentin. Oper Dent. 2015 Sep-Oct;40(5):E206-21. http://dx.doi.org/10.2341/14-115-L. PMid:26237639.

19. Machado FW, Bossardi M, Ramos TS, Valente LL, Münchow EA, Piva E. Application of resin adhesive on the surface of a silanized glass fiber-reinforced post and its effect on the retention to root dentin. J Endod. 2015 Jan;41(1):106-10. http://dx.doi.org/10.1016/j.joen.2014.09.014. PMid:25442719.

20. Leme AA, Pinho AL, Gonçalves L, Correr-Sobrinho L, Sinhoreti MA. Effects of silane application on luting fiber posts using self-adhesive resin cement. J Adhes Dent. 2013 Jun;15(3):269-74. http://dx.doi.org/10.3290/j.jad.a28881. PMid:23534023.

21. Perdigão J, Geraldeli S, Lee IK. Push-out bond strengths of tooth-colored posts bonded with different adhesive systems. Am J Dent. 2004 Dec;17(6):422-6. PMid:15724754.

22. Pulido CA, de Oliveira Franco AP, Gomes GM, Bittencourt BF, Kalinowski HJ, Gomes JC, et al. An in situ evaluation of the polymerization shrinkage, degree of conversion, and bond strength of resin cements used for luting fiber posts. J Prosthet Dent. 2016 Oct;116(4):570-6. http://dx.doi.org/10.1016/j.prosdent.2016.02.019. PMid:27157607.

23. Hikita K, Van Meerbeek B, De Munck J, Ikeda T, Van Landuyt K, Maida T, et al. Bonding effectiveness of adhesive luting agents to enamel and dentin. Dent Mater. 2007 Jan;23(1):71-80. http://dx.doi.org/10.1016/j.dental.2005.12.002. PMid:16426673.

24. Armstrong S, Geraldeli S, Maia R, Raposo LH, Soares CJ, Yamagawa J. Adhesion to tooth structure: a critical review of "micro" bond strength test methods. Dent Mater. 2010 Feb;26(2):e50-62. http://dx.doi.org/10.1016/j.dental.2009.11.155. PMid:20045179.

25. Goracci C, Sadek FT, Monticelli F, Cardoso PE, Ferrari M. Influence of substrate, shape, and thickness on microtensile specimens' structural integrity and their measured bond strengths. Dent Mater. 2004 Sep;20(7):643-54. http://dx.doi.org/10.1016/j.dental.2003.08.009. PMid:15236939.

\section{CONFLICTS OF INTERESTS}

The authors declare no conflicts of interest.

\section{${ }^{*}$ CORRESPONDING AUTHOR}

Gabriela Simões Teixeira, Avenida Roraima, 1000, Prédio 26F, Sala 2248, 97105-900 Santa Maria - RS, Brasil, e-mail: gsimoesteixeira@gmail.com

Received: March 21, 2019

Accepted: August 7, 2019 